\title{
A well-preserved bimodal Archaean volcanic succession in the Tasiusarsuaq terrane, South-West Greenland
}

\author{
Henrik Stendal and Anders Scherstén
}

During the field campaign in the Nuuk region, one of the objectives was to describe Archaean primary geological environments (Hollis et al. 2006). On Nunatak 1390, which is part of the Tasiusarsuaq terrane (Figs 1, 2), a bimodal volcanic succession is preserved and interpreted as former ocean floor. The field investigation included geological mapping and sampling of the volcanic sequence comprising mafic to ultramafic rocks, and associated acid volcanic rocks and granite intrusions.

\section{The Tasiusarsuaq terrane}

The Tasiusarsuaq terrane is dominated by mafic rocks (amphibolite), tonalitic gneiss and granodiorite yielding ages of 2.922.86 Ga (Fig. 1; Schiøtte et al. 1989; Friend \& Nutman 2001; Crowley 2002). Metamorphic grade ranges from greenschist to granulite facies conditions, with peak metamorphism dated at $-2.79 \mathrm{Ga}$ (Pidgeon \& Kalsbeek 1978). The mafic rocks comprise greenschist facies mafic rocks with pillow structures, metagabbroic and ultramafic pods, and dykes. The thicknesses of the mafic to ultramafic sequences vary from $50 \mathrm{~m}$ up to more than $1000 \mathrm{~m}$. The Tasiusarsuaq terrane rocks are cross-cut by brown-weathering E-W-trending dolerite dykes (up to $30 \mathrm{~m}$ wide) with well-developed chilled margins. Alterations such as calc-silicate formation are common within the maficultramafic rocks. The pillowed mafic sequences contain intercalations of 1-2 m wide, rusty, sulphide-bearing layers and tourmalinites (exhalites). The sulphides recorded include pyrite, pyrrhotite, chalcopyrite and arsenopyrite.

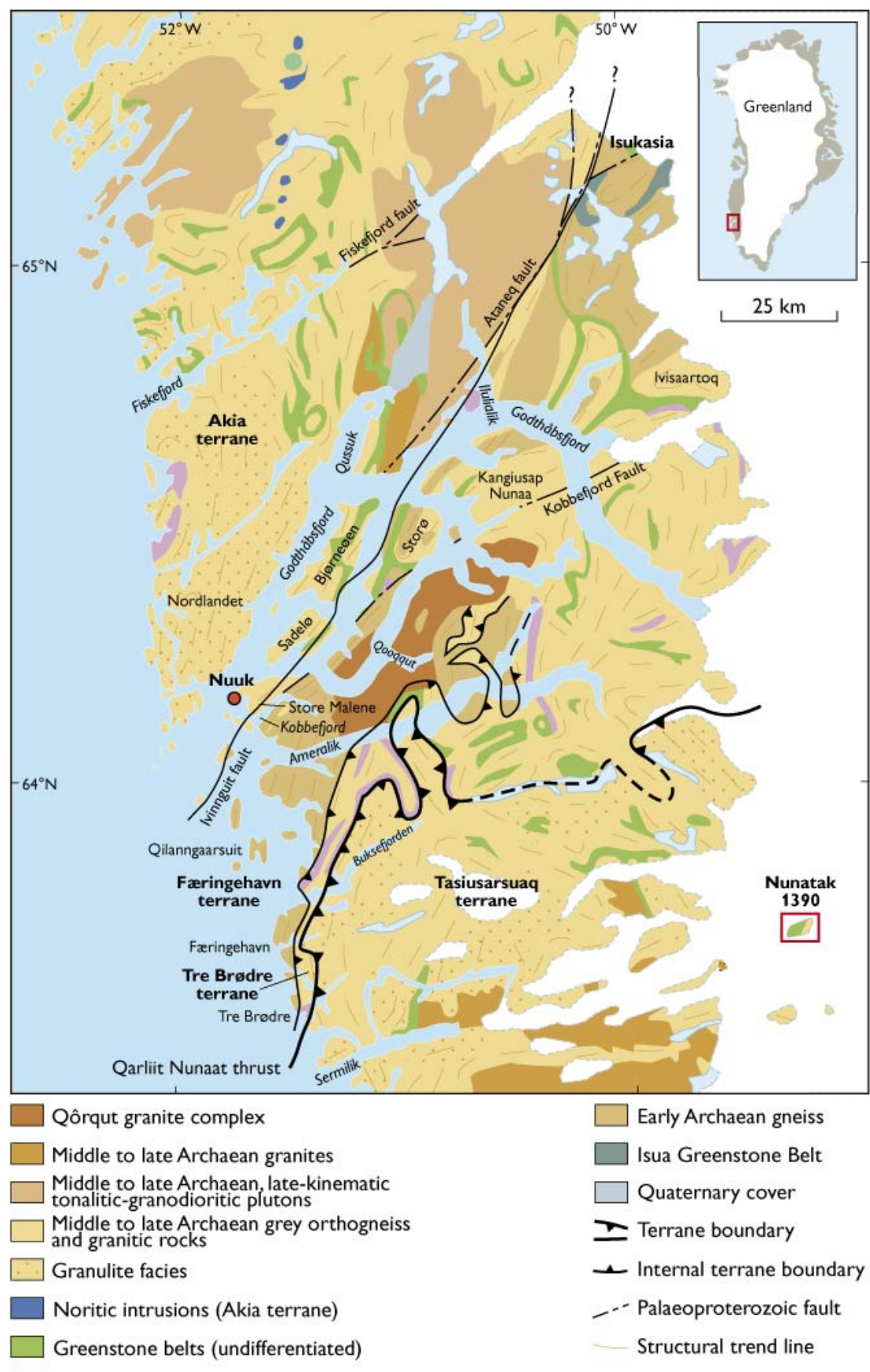

Anorthosite-gabbro complexes

Fig. 1. Geological map of the Nuuk region and location of the Nunatak 1390 study area (modified from Escher \& Pulvertaft 1995). 


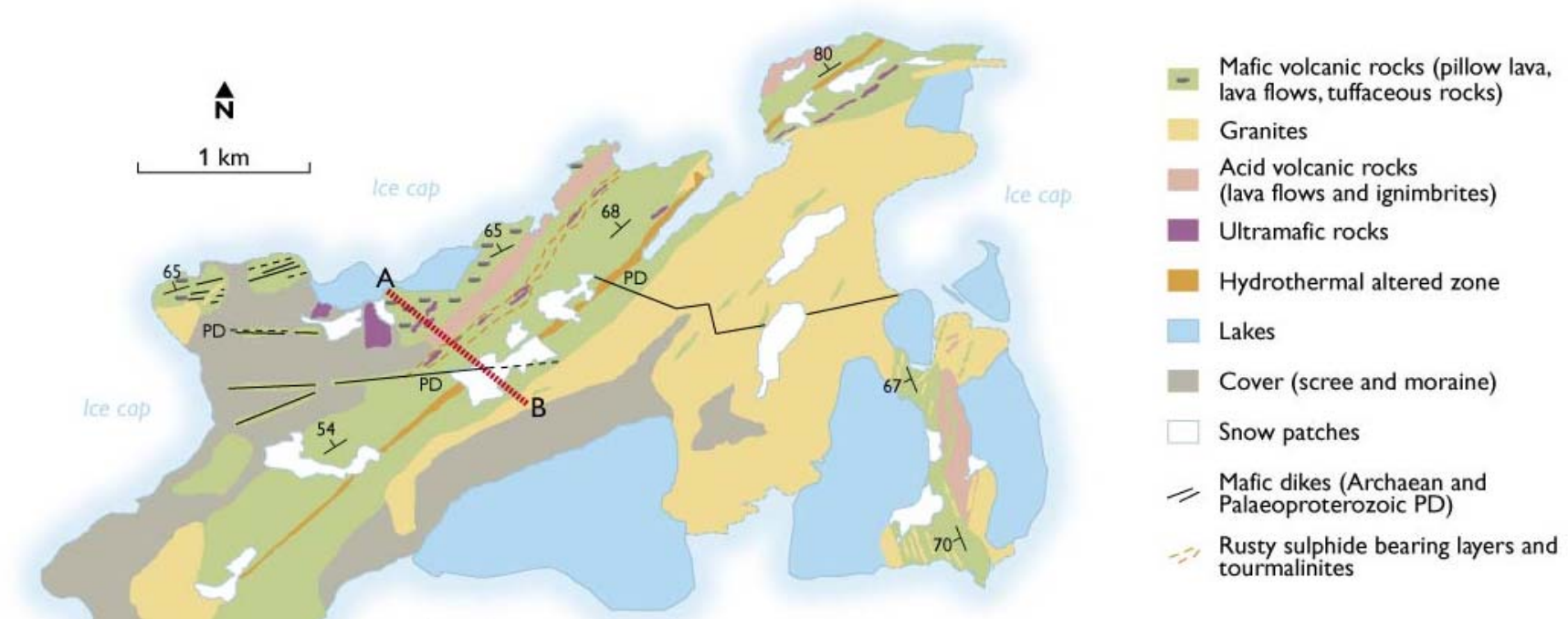

\section{Nunatak 1390}

Nunatak 1390 is located within the Inland Ice east of Alangorlia and was first described by Escher \& Pidgeon (1976; Figs 1, 2). The entire volcanic package (Fig. 3; Table 1 ) is north-east-striking and dips steeply to the north-west. Although slightly to moderately deformed with lineations, folding, faulting and shearing, the rocks show well-preserved primary textures.

\section{Stratigraphy}

The lower mafic pillow sequence shows large deformed pillow structures (50-100 cm across) and pillow breccias with calc-silicate alteration in the matrix between the pillows and in the centre of some pillows. The calc-silicate minerals include epidote, diopside and carbonates and make up to 20 vol.\% of the rock. The pillowed sequence is cut by a slightly deformed E-W-trending swarm of mafic dykes (1-5 m thick). The dykes are fine- to medium-grained gabbroic or noritic rocks.
Fig. 2. Geological map of Nunatak 1390. Profile A-B is described in Table 1 and shown in Fig. 3. PD, Palaeoproterozoic dyke. For location see Fig. 1

Ultramafic greenstones and soapstones occur between the upper and lower pillow lava sequences. These magnetitebearing rocks were probably originally sills. The upper pillow sequence contains very well-preserved primary structures in pillows, lava flows and ash layers (Fig. 4). The least deformed pillow lavas and flows contain relic vesicles. Way-up can readily be determined from the pillow structures and consistently youngs to the south. The upper mafic pillow sequence is overlain by a unit of acid volcanic and pyroclastic rocks, including ignimbrites, $80 \mathrm{~m}$ in thickness (Fig. 5). Finegrained, grey to light-coloured porphyritic dykes $(0.3-0.8 \mathrm{~m}$ wide) cut the volcanic rocks and are interpreted as feeder dykes to the acid rocks. Mafic flows and ash layers are intercalated with ultramafic sills, and mafic rusty layers contain sulphides and tourmalinites. The tourmalinite forms an up to one metre thick layer.

A prominent hydrothermal zone, strongly silicified and epidotised, strikes parallel with the mafic ash layers. It follows

Table 1. Stratigraphy of the volcanic sequence on Nunatak 1390

\begin{tabular}{lcl}
\hline Rock type & Thickness $(\mathrm{m})$ & \\
\hline Mafic dyke & $1-20$ & Undeformed Palaeoproterozoic brown dykes \\
Granite(s) & $?$ & Porphyritic granite, altered granite and pegmatite \\
Tuff & $700-800$ & Finely laminated tuff layers intruded by granitoids \\
Hydrothermally altered zone & 50 & Altered mafic tuff, and silicified and epidotised rocks \\
Mafic volcanic flows/tuff & 120 & Basaltic-komatiitic/mafic-ultramafic flows and tuff, intercalated with ultramafic sills, \\
Acid flows and pyroclastites & 80 & mafic rusty layers, sulphides (exhalites) and tourmalinites \\
Upper mafic volcanic pillows & $\sim 200$ & Acid lava flows and ignimbrites \\
Ultramafic greenstone/sill & $10-50$ & $25-100$ cm large pillows, pillow breccias and calc-silicate alterations \\
Lower mafic pillow sequence & $>500$ & Ultramafic greenstone/sill between lower and upper pillow sequence
\end{tabular}




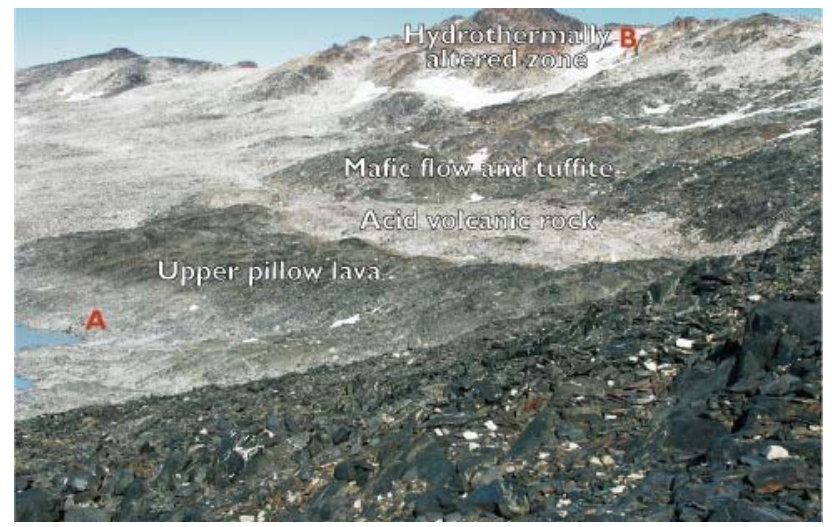

Fig. 3. Central part of the stratigraphy of profile A-B on Nunatak 1390 (see Table 1).

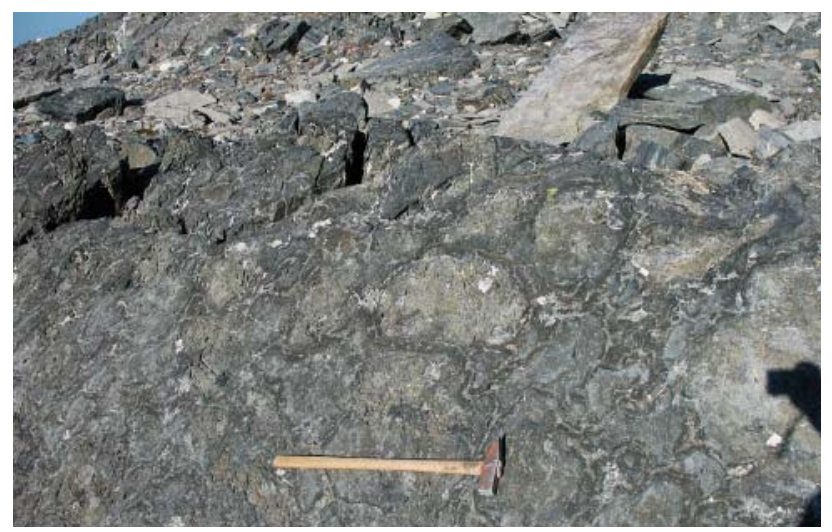

Fig. 4. Pillow lava structures in the upper pillow lava sequence. Hammer $(50 \mathrm{~cm})$ for scale.

a fault lineament, is up to $50 \mathrm{~m}$ wide and can be recognised from the light brownish surface colour of the altered rocks. The hydrothermal zone is overlain by a thick sequence $(700-800 \mathrm{~m})$ of finely laminated tuff layers. Granite intrusions in the tuffs increase in abundance upwards and pass upwards into porphyritic granite with tuff xenoliths.

Two phases of granite occur: one is porphyritic with Kfeldspar phenocrysts up to several centimetres in length; the other is more homogeneous, medium-grained, slightly foliated and muscovite-bearing. Parts of the granites, especially in the western part of the exposure, are altered and have a distinct pink coloration due to hematite formation.

On a regional scale, it should be noted that western and southern parts of the Tasiusarsuaq terrane preserve remnants of volcanic rocks at several localities, probably of similar age to that on Nunatak 1390 (Escher \& Myers 1975).

\section{Geochemistry}

Twenty samples representing most rock types found on Nunatak 1390 were analysed by Actlabs, Canada (Research Package 4E). Altered samples were screened using e.g. $\mathrm{K} 2 \mathrm{O} / \mathrm{P} 2 \mathrm{O} 5$, and those with anomalous ratios are not con-

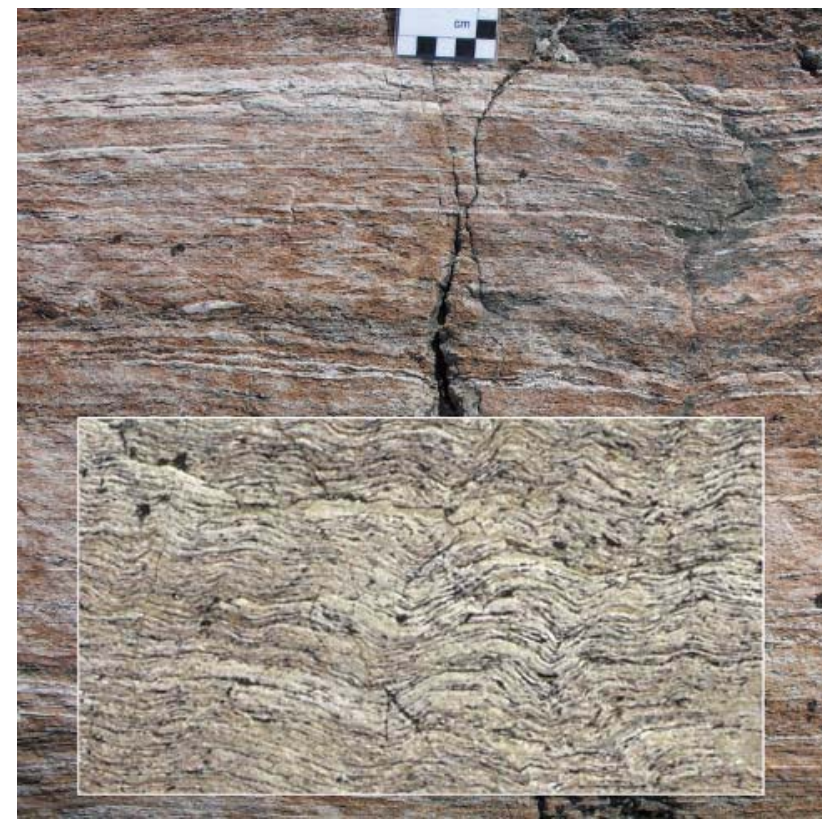

Fig. 5. Laminated acid volcanic rock (ignimbrite). Inset is an enlargement (inset is about $5 \mathrm{~cm}$ wide).

sidered any further. Melanocratic-ultramafic pillow lavas, flows and ash have komatiitic and $\mathrm{Mg}$ - and Fe-rich basalt compositions and plot along a well-defined tholeiitic trend (Fig. 6A). The acid rock, which intercalates with the tholeiites, forms a loosely defined calc-alkaline group of andesitic to dacitic composition (Fig. 6A).

The tholeiites are characterised by near chondritic relative REE abundances (mean La/SmN $=1.2 \pm 0.41 \sigma ; \mathrm{La} / \mathrm{YbN}=$ $1.3 \pm 0.31 \sigma, \mathrm{n}=9$ ), while the acid rocks are more enriched and varied in their LREE (mean La/SmN $=5 \pm 11 \sigma ; \mathrm{La} / \mathrm{YbN}$ $=24 \pm 171 \sigma, \mathrm{n}=5$; Fig. 6B). The different incompatible trace element abundances in the tholeiites and acid rocks persist through all the elements, albeit with more scatter in the mobile elements. Important immobile, incompatible element ratios are indicative of potentially different tectonic settings for the tholeiites and the acid rocks. $\mathrm{Nb} / \mathrm{La}$ ratios do not vary with $\mathrm{Nb}$ or other incompatible elements, which implies insignificant effects of fractional crystallisation and insignificant amounts of crustal contamination (Fig. 6C). The tholeiite mean $\mathrm{Nb} / \mathrm{La}$ ratio is $0.6 \pm 0.1(1 \sigma ; \mathrm{n}=9)$, while the acid rocks have a substantially lower ratio of $0.14 \pm 0.03(1 \sigma ; n=5)$. The ratios of the tholeiites are reminiscent of lower crust, while the low ratios of the acid rocks are typical of volcanic arc related rocks (Hawkesworth \& Kemp 2006). Even though metamorphic element mobility may disturb e.g. $\mathrm{Ce} / \mathrm{Pb}$ ratios, the consistent and low ratios of the acid rocks corroborate an arc origin (Fig. 6D), which we postulate for these rocks. The tholeiites are more ambiguous and are akin to MORB or island arc tholeiites. The spatial relationship 

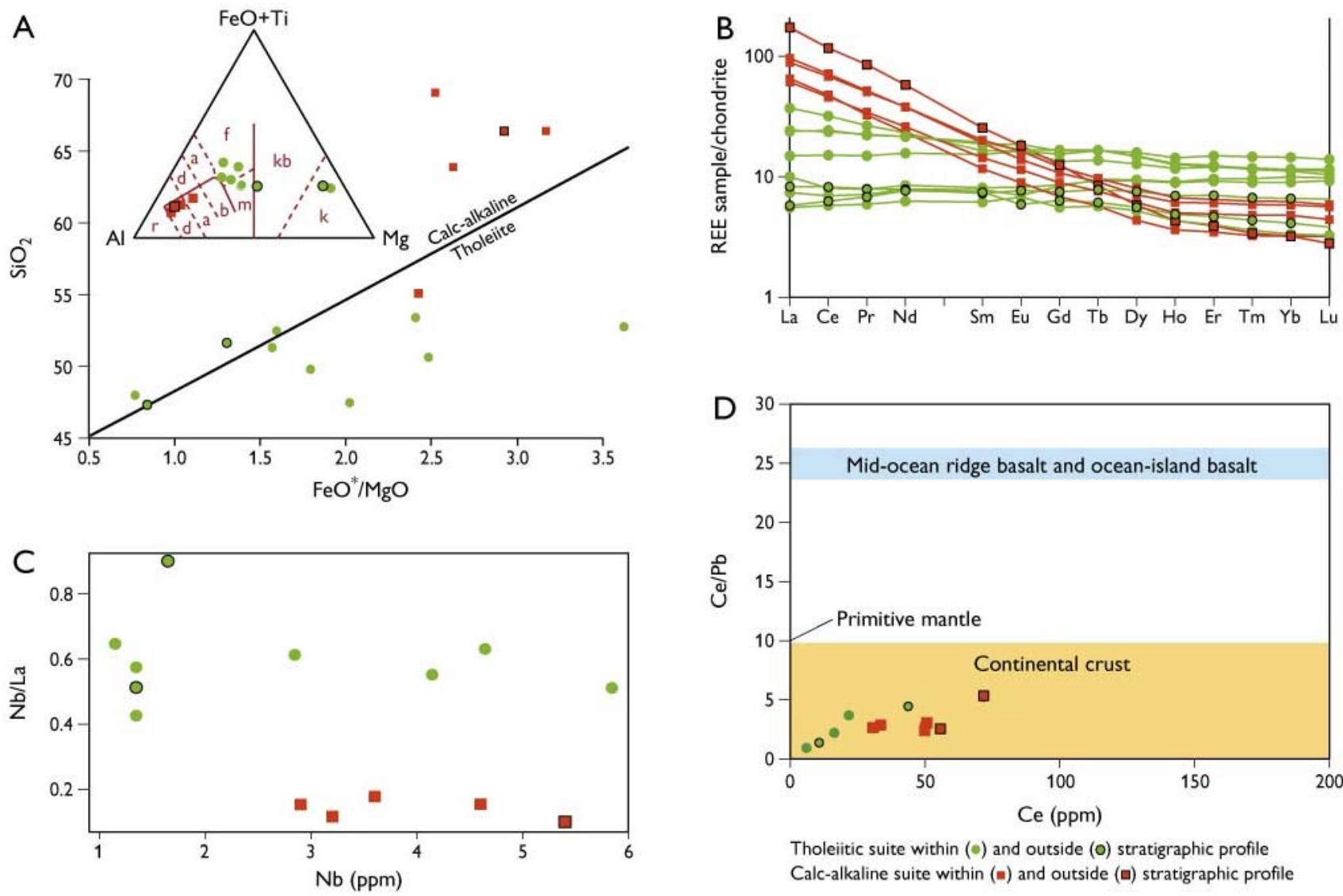

Tholeiitic suite within (०) and outside (o) stratigraphic profile Calc-alkaline suite within $(\Xi)$ and outside $(\square)$ stratigraphic profile

Fig. 6. A: $\mathrm{FeO}_{\mathrm{t}} / \mathrm{MgO}$ versus $\mathrm{SiO}_{2}$ variation diagram, and Jensen cation plot; rhyolite (r), dacite (d), andesite (a), basalt (b), Mg tholeiite basalt (m), Fe tholeiite basalt (f), komatiitic basalt $(\mathbf{k b})$ and komatiite $(\mathbf{k})$. B: REE distribution of the tholeiitic suite (green) and calc-alkaline suite (red). C: Nb versus $\mathrm{Nb} / \mathrm{La}$ of the tholeiitic suite (green) and calc-alkaline suite (red). $\mathbf{D}$ : Ce/ $\mathrm{Pb}$ ratios variation versus Ce of the tholeiitic suite (green) and calc-alkaline suite (red).

between the acid rocks and the tholeiites seems to support a common origin, in which case an arc setting seems most plausible. By analogy with modern arc systems, the two components may reflect input from trench-side (tholeiites) and back arc-side (calc-alkaline) volcanoes respectively, or temporal shifts in the petrogenetic processes.

\section{References}

Crowley, J.L. 2002: Testing the model of late Archean terrane accretion in southern West Greenland: a comparison of the timing of geological events across the Qarliit nunaat fault, Buksefjorden region. Precambrian Research 116, 57-79.

Escher, J.C. \& Myers, J.S. 1975: New evidence concerning the original relationships of early Precambrian volcanics and anorthosites in the Fiskenæsset region, southern West Greenland. Rapport Grønlands Geologiske Undersøgelse 75, 72-76.

Escher, J.C. \& Pidgeon, R.T. 1976: Field mapping of nunatak 1390 m, east of Alángordlia, southern West Greenland. Rapport Grønlands Geologiske Undersøgelse $\mathbf{8 0}, 84-87$.
Escher, J.C. \& Pulvertaft, T.C.R. 1995: Geological map of Greenland, 1:2 500 000. Copenhagen: Geological Survey of Greenland.

Friend, C.R.L. \& Nutman, A.P. 2001: U-Pb zircon study of tectonically bounded blocks of 2940-2840 Ma crust with different metamorphic histories, Paamiut region, South-West Greenland: implications for the tectonic assembly of the North Atlantic craton. Precambrian Research 105, 143-164.

Hawkesworth, C.J. \& Kemp, A.I.S. 2006: Evolution of the continental crust. Nature 443, 811-817.

Hollis, J.A., Schmid, S., Stendal, H., van Gool, J.A.M. \& Weng, W.L. 2006: Supracrustal belts in Godthåbsfjord region, southern West Greenland. Progress report on 2005 field work: geological mapping, regional hydrothermal alteration and tectonic sections. Danmarks og Grønlands Geologiske Undersøgelse Rapport 2006/7, 171 pp.

Pidgeon, R.T. \& Kalsbeek, F. 1978: Dating of igneous and metamorphic events in the Fiskenaesset region of southern West Greenland. Canadian Journal of Earth Sciences 15, 2021-2025.

Schiøtte, L., Compston, W. \& Bridgwater, D. 1989: U-Pb single-zircon age for the Tinissaq gneiss of southern West Greenland: a controversy resolved. Chemical Geology (Isotope Geoscience Section) 79, 21-30.

\section{Authors' address}

Geological Survey of Denmark and Greenland, Øster Voldgade 10, DK-1350 Copenhagen K, Denmark. E-mail: hst@geus.dk. 